\title{
JUURNAL.RU
}

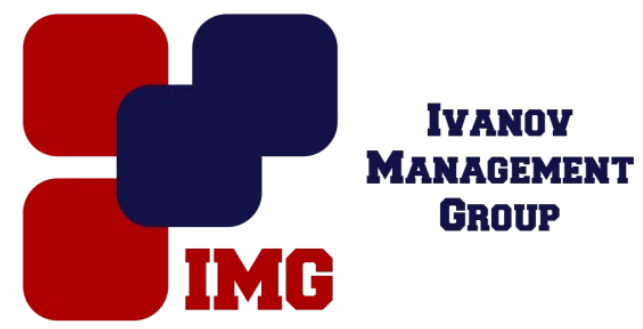

Грушевая Т.Д., Колмык К.А.

doi: 10.18411/lj-25-12-2016-2-03

idsp 000001:lj-25-12-2016-2-03

\section{Таможенные правонарушения}

Таможенные органы имеют право во исполнение решений высших федеральных органов издавать акты управления по вопросам таможенного дела, которые обязательны для исполнения иными ведомствами, юридическими и физическими лицами, имеющими отношение к перемещению товаров и транспортных средств через таможенную границу.

Таможенные органы также являются органами осуществляющими охрану урегулированных нормами таможенного, административного, уголовного, государственного, международного, финансового, гражданского и иных отраслей права отношений, которые возникают в процессе взаимоотношений участников ВЭД и должностных лиц таможенных органов по вопросам перемещения товаров и транспортных средств через таможенную границу.

Конституция РФ устанавливает, что все граждане и государственные органы должны выполнять требования правовых норм. Регулируя ВЭД, таможенные органы способствуют развитию торговли между Россией и иными странами.

Состав нарушения таможенных правил - это логическая конструкция, это правовое понятие о нем, которое отражает существенные признаки определенных антиобщественных деяний в сфере таможенного дела. Законодатель сам не создает признаков таможенных правонарушений, он лишь отбирает существенные и отличительные черты и конструирует составы. Логическая конструкция закрепляется в праве и становится обязательной. Перечень закрепленных в ней признаков является необходимым и достаточным основанием для квалификации деяния как нарушения таможенных правил. Иными словами, реальное деяние только тогда может рассматриваться в качестве нарушения таможенных правил, когда оно содержит все признаки его состава, а отсутствие хотя бы одного из них означает и отсутствие состава в целом.

Исчерпывающий перечень объектов нарушений таможенных правил:

- порядок перемещения товаров и транспортных средств через таможенную границу России;

- порядок таможенного контроля товаров и транспортных средств, перемещаемых через таможенную границу России; 
- порядок таможенного оформления товаров и транспортных средств, перемещаемых через таможенную границу России;

- порядок обложения перемещаемых через таможенную границу России товаров и транспортных средств таможенными платежами и порядок их уплаты;

- порядок предоставления в отношении указанных выше товаров и транспортных средств таможенных льгот и порядок пользования ими.

В качестве субъекта нарушения таможенных правил может рассматриваться любое лицо (физическое или юридическое), которое подлежит ответственности за предусмотренные таможенным законодательством деяния (действия либо бездействия), связанные с нарушением правил, соблюдение которых входит в его установленные законом или иным нормативно-правовым актом обязанности в сфере таможенного дела.

Различают следующие виды нарушений таможенных правил:

$>$ нарушение режима зоны таможенного контроля;

$>$ неуведомление при ввозе товаров и транспортных средств о пересечении таможенной границы РФ;

неуведомление или недостоверное уведомление о намерении вывезти товары и транспортные средства за пределы таможенной территории РФ;

$>$ непринятие мер в случае аварии или действия непреодолимой силы;

$>$ непредставление товаров и транспортных средств в месте доставки и невручение документов на них;

> выдача без разрешения таможенного органа РФ, утрата или недоставление в таможенный орган РФ товаров, транспортных средств и документации на них;

$>$ неостановка транспортного средства;

$>$ причаливание к судну и другим плавучим средствам, находящимся под таможенным контролем;

$>$ нарушение порядка производства таможенного оформления;

$>$ неправомерные операции с товарами и транспортными средствами, в отношении которых таможенное оформление не завершено, изменение их состояния, пользование и распоряжение ими;

$>$ грузовые и иные операции, проводимые без разрешения таможенного органа РФ;

$>$ изменение, уничтожение, повреждение либо утрата средств идентификации;

$>$ нарушение порядка декларирования товаров и транспортных средств;

$>$ нарушение сроков представления таможенному органу РФ таможенной декларации, документов и дополнительных сведений;

воспрепятствование доступу должностного лица таможенного органа РФ на территорию и в помещение для проведения таможенного контроля;

$>$ непредставление таможенному органу РФ отчетности и несоблюдение порядка ведения учета;

нарушение режима склада временного хранения; 
$>$ нарушение порядка помещения товаров на хранение, их хранения и проведения операций с ними;

$>$ нарушение порядка переработки товаров;

$>$ нарушение порядка осуществления производственной и иной коммерческой деятельности в свободных таможенных зонах и на свободных складах;

$>$ нарушение порядка возведения зданий, строений и сооружений в свободных таможенных зонах;

$>$ невывоз за пределы таможенной территории РФ либо невозвращение на эту территорию товаров и транспортных средств;

$>$ нарушение порядка уничтожения товаров;

> неправомерные операции с товарами и транспортными средствами, помещенными под определенный таможенный режим, изменение их состояния, пользование и распоряжение ими;

$>$ несоблюдение порядка применения мер экономической политики и других ограничений при перемещении товаров и транспортных средств через таможенную границу РФ;

$>$ перемещение товаров через таможенную границу РФ под видом товаров не для коммерческих целей;

> перемещение товаров и транспортных средств через таможенную границу РФ помимо таможенного контроля;

сокрытие от таможенного контроля товаров, перемещаемых через таможенную границу РФ;

$>$ перемещение товаров и транспортных средств через таможенную границу РФ с обманным использованием документов и средств идентификации;

$>$ недекларирование или недостоверное декларирование товаров и транспортных средств;

$>$ транспортировка, хранение, приобретение товаров и транспортных средств, ввезенных на таможенную территорию РФ с нарушениями таможенных правил, пользование или распоряжение ими;

$>$ действия, направленные на неправомерное освобождение таможенных платежей или их занижение;

$>$ действия, направленные на возврат уплаченных таможенных платежей, получение выплат и иных возмещении либо их невозвращение без надлежащих оснований;

$>$ нарушение сроков уплаты таможенных платежей;

$>$ неисполнение банками и иными кредитными учреждениями решений таможенных органов РФ;

$>$ незаконное осуществление деятельности в качестве таможенного брокера либо нарушение условий такой деятельности;

незаконное осуществление деятельности в качестве таможенного перевозчика либо нарушение условий такой деятельности;

невыполнение должностными и иными лицами требований, действующих в таможенном деле.

Под взысканием за нарушение таможенных правил понимается мера административной ответственности, применяемая к лицу, совершившему 
нарушение таможенных правил.

За совершение нарушений таможенных правил законодательство предусмотрело следующие виды взысканий:

$\checkmark$ предупреждение;

$\checkmark$ штраф;

$\checkmark$ отзыв лицензии или квалификационного

аттестата, выданного таможенным органом на осуществление определенных видов деятельности в сфере таможенного дела;

$\checkmark$ конфискацию товаров и транспортных средств, являющихся непосредственными объектами нарушения таможенных правил; товаров и транспортных средств со специально изготовленными тайниками, использованными для перемещения через таможенную границу России с сокрытие предметов, являющихся непосредственными объектами нарушения таможенных правил;

$\checkmark$ взыскание стоимости товаров и транспортных средств, являющихся непосредственными объектами нарушения таможенных правил, товаров и транспортных средств со специально изготовленными тайниками, использованными для перемещения через таможенную границу России с сокрытием предметов, являющихся непосредственными объектами нарушения таможенных правил;

$\checkmark$ конфискацию транспортных средств, на которых перевозились товары, являющиеся непосредственными объектами нарушения таможенных правил.

Все эти виды взысканий тесно связаны между собой и составляют единую систему, поскольку все их объединяет одна общая цель: защита правопорядка в сфере таможенного дела, воздействие на лиц, совершивших нарушение таможенных правил, и предупреждение совершения новых таможенных правонарушений.

Взыскания за нарушение таможенных правил могут быть разовыми, единовременными (предупреждение, штраф, взыскание стоимости и конфискация) и длящимися, растянутыми во времени, когда лицо, на которое наложено взыскание, в течение определенного времени не имеет права заниматься определенного рода деятельностью (сюда относится отзыв лицензии или квалификационного аттестата).

По наиболее актуальным и сложным вопросам производства по административным правонарушениям в области таможенного дела ФТС России издает методические рекомендации.

Глава 16 КоАП РФ "Административные правонарушения в области таможенного дела (нарушения таможенных правил)", которая входит в административную юрисдикцию таможенных органов, содержит 23 статьи и 47 составов административных правонарушений в области таможенного дела. Из них 10 статей, объединяющих 16 составов, предусматривают назначение административного наказания в соответствии со ст. 3.7 КоАП РФ ("Конфискация орудий совершения или предмета административного правонарушения"). В соответствии со ст. 23.8. КоАП РФ таможенные органы рассматривают дела об административных правонарушениях, предусмотренных ч. 1 и 3 ст. 16.1, ст. 16.216.23 КоАП РФ. 
В целом состояние административного законодательства позволяет должностным лицам таможенных органов в настоящее время эффективно осуществлять производство по административным правонарушениям в области таможенного дела.

Наряду с этим необходимо отметить: несмотря на проводимую либерализацию таможенного и административного законодательства, количество дел об административных правонарушениях в области таможенного дела остается значительным и имеет тенденцию к росту.

Таким образом, характеризуя деятельность должностных лиц таможенных органов, осуществляющих производство но делам об административных правонарушениях в области таможенного дела, необходимо отметить определенные особенности указанного производства:

- производство по делам об административных правонарушениях в области таможенного дела является разновидностью производства по делам об административных правонарушениях и регулируется нормами КоАП РФ и Таможенного кодекса ТС;

- основными субъектами правонарушений являются физические лица, что свидетельствует о сложности привлечения юридических лиц за административные правонарушения в области таможенного дела, так как нормы КоАП РФ (ст. 2.1 и др.) не четко регламентирует данную процедуру;

- в большинстве случаев производство проводиться по наиболее общественно опасным нарушениям таможенных правил (так называемых контрабанднообразующих составов), сопряженных с недекларированием и недостоверным декларированием товаров, а также с ввозом товаров в нарушение установленных запретов и ограничений, наносящих существенный ущерб интересам государства (ст. 16.1, 16.2, 16.3 КоАП РФ), которые составляют более 30\% от общего количества дел;

- основными административными наказаниями по данным делам за исследуемый период являлись "административный штраф" и "конфискация орудий или предметов административного правонарушения";

- возбуждение дел и производство по делам о нарушении таможенных правил осуществляется широким кругом уполномоченных должностных лиц таможенных органов;

- сложность и проблематичность ведения производства в отношении иностранных граждан - участников ВЭД, которые после возбуждения дела о нарушении таможенных правил в ряде случаев покидают территорию РФ и уклоняются от административной ответственности;

- в ряде случаев возбуждению и производству по делам об административных правонарушениях в области таможенного дела способствует низкая эффективность работы органов дознания отдельных таможен;

- в связи с несовершенством норм административного законодательства и исполнительного производства практически во всех таможенных 
органах наблюдается низкая взыскиваемость административных штрафов;

- остается значительным количество актов прокурорского реагирования по административным правонарушениям в области таможенного дела.

- Таким образом, в целях дальнейшего совершенствования административного и таможенного законодательства для повышения эффективности и целесообразности производства по делам об административных правонарушениях в области таможенного дела предлагается:

- совершенствовать нормы КоАП РФ и других нормативных правовых актов, касающихся производства по данным делам;

- исключить необоснованное возбуждение дел об административных правонарушениях в области таможенного дела, возбуждения административного производства без установления достаточных данных, указывающих на наличие события административного правонарушения;

- упорядочить применение ст. 2.9 КоАП России о малозначительности административного правонарушения;

- при необходимости производить изъятие или арест товаров и транспортных средств, являющихся предметами административного правонарушения, а также применять другие меры обеспечения производства;

- конкретизировать методику производства административного расследования и других процессуальных действий;

- установить ответственность лиц за отказ от дачи показаний и неявку без уважительной причины при производстве по делам об административных правонарушениях в области таможенного дела;

- исключить возбуждение дел об административных правонарушениях при наличии признаков уголовно наказуемых деяний;

- активизировать взаимодействие руководящего состава таможенных органов с надзирающими органами по предупреждению и пресечению нарушении законности при производстве по делам об административных правонарушениях в области таможенного дела должностными лицами таможенных органов;

- повысить роль ФТС России и региональных (центральных) таможенных управлений по организации и проведению ведомственного контроля за производством по делам об административных правонарушениях в области таможенного дела.

Правоохранительная деятельность таможенных органов является, одной из важнейших форм государственного контроля. Таможни Российской Федерации, являясь правоохранительными органами, компетентны решать все вопросы, касающиеся осуществления таможенного дела на своей территории. Как и региональные управления, таможни осуществляют проведение на своей территории таможенной политики независимо от того, идет ли речь о перемещении через таможенную границу или о борьбе с контрабандой или иными преступлениями в этой сфере. Борьба с преступлениями, совершаемыми в 
таможенной сфере, с учетом их большой общественной опасности, должна вестись всеми предусмотренными законом средствами и, разумеется, только в рамках закона.

Для выявления всех проблем, связанных с привлечением к ответственности за совершение административных правонарушений в сфере таможенного дела, и поиска возможных путей их решения требуется более детальное изучение данной темы.

\section{Литература}

1. Андриашин Х.А., Свинухов В.Г., Балакин В.В. Таможенное право. М.: Магистр, 2008г.-367с.

2. Бакаева О.Ю., Матвиенко Г.В Таможенное право. Курс лекций. . М.: РАП, Эксмо, 2009. - 272 с.

3. Бакаева О.Ю., Матвиенко Г.В Таможенное право России. 2-е изд., перераб. и доп. - М.: Юристь, 2007. - 504 с.

4. Коник Н.В., Невешкина Е.В. Таможенное дело. Научная книга, Издательство: «Омега-Л» 2012. - 154 с.

5. Коник Н.В. „Невешкина Е.В. Таможенное дело. Учебное пособие. 3-е изд. Издательство: «Омега-Л», 2014 - 203с.

6. Тимошенко И.В.. Таможенное право: конспект лекций / И.В. Тимошенко - Ростов п/Д : Феникс ,. - (Зачет и экзамен).. 2007.- 317 с.

7. Халипов С.В. Таможенное право. 3-е изд., перераб. и доп. - М.: Зерцало-М, 2006. - 440 с

8. Х Халипов С.В. Таможенное право: вопросы и ответы. 4-е изд., доп. / С.В. Халипов. - М.: ИД «Юриспруденция», 2015. - 182 с.

9. Чинько В.А. Таможенное право. Шпаргалки. Издательство: Эксмо; 2007г., 32 стр.

10. Таможенный кодекс Таможенного Союза. ред. от 08.05.2015 http://www.consultant.ru/document/cons_doc_LAW_94890/

11. Кодекс Российской Федерации об административных правонарушениях N 195-Ф3 от 30.12.2001 (ред. от 05.12.2016) http://www.consultant.ru/document/cons_doc_LAW_34661/ 